ח

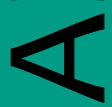

n

Ш

Z

O

$\underline{-}$

$F$

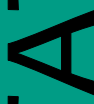

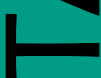

ه

Ш

n

n

$\overline{0}$
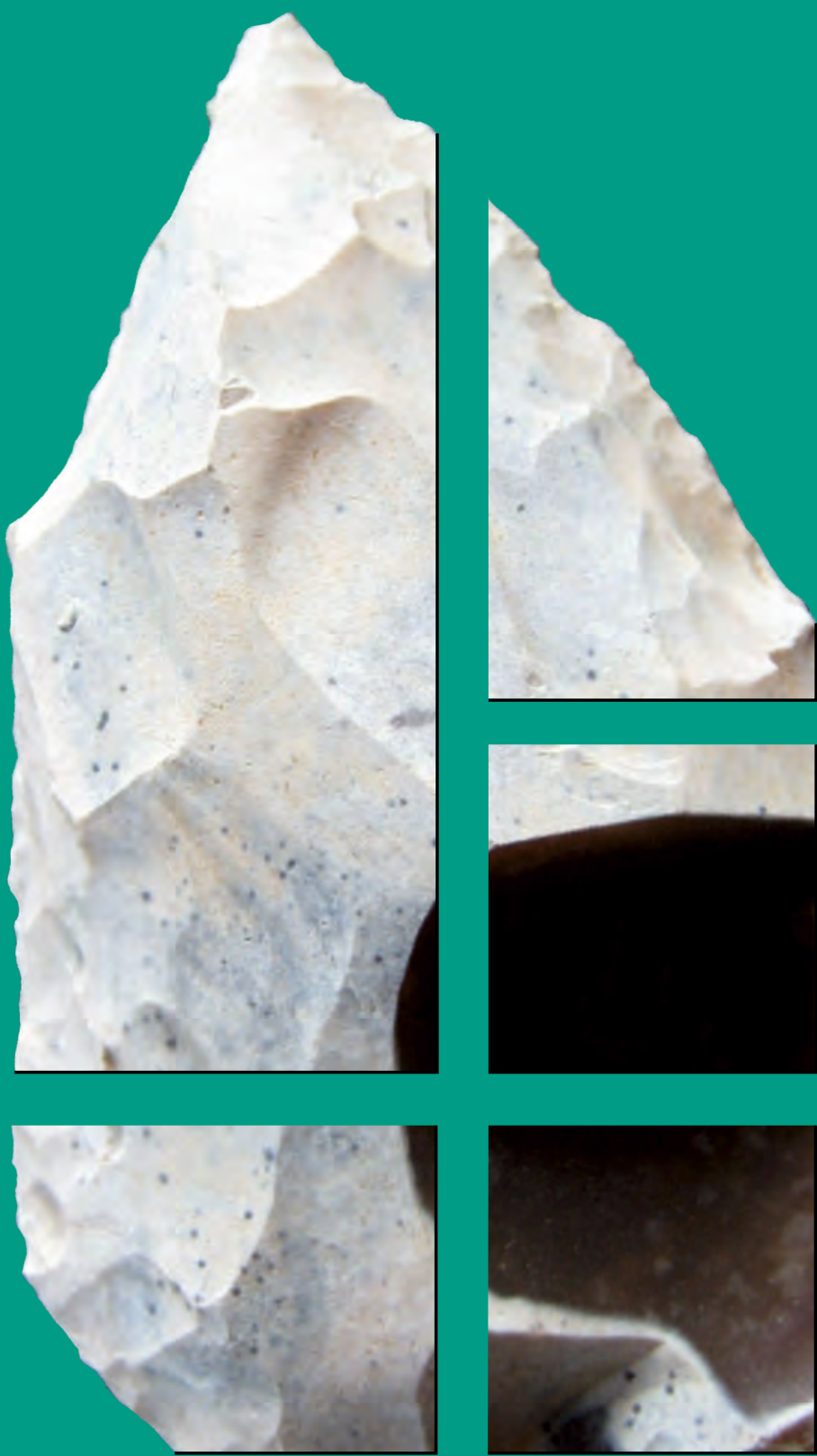

Ser. 3. No.9.| 2021 


\section{Dissertationes Archaeologicae ex Instituto Archaeologico}

Universitatis de Rolando Eötvös nominatae

Ser. 3. No. 9.

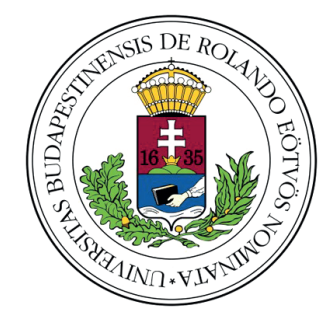

Budapest 2021 


\section{Dissertationes Archaeologicae ex Instituto Archaeologico Universitatis de Rolando Eötvös nominatae}

Ser. 3. No. 9.

Editor-in-chief

Dávid BARTus

Editorial board

László Bartosiewicz (Stockholm University, Stockholm)

Ondřej Chvojкa (University of South Bohemia, České Budějovice)

Zoltán Czajlik (Eötvös Loránd University, Budapest)

Mario Gavranović (Austrian Arhaeological Institute AAS, Vienna)

Hajnalka Herold (University of Exeter, Exeter)

Klára Kuzmová (University of Trnava, Trnava)

Tina Milavec (University of Ljubljana, Ljubljana)

Gábor V. Szabó (Eötvös Loránd University, Budapest)

Tivadar VIDA (Eötvös Loránd University, Budapest)

Technical editor

Gábor VÁcZI

Proofreading

Eszter TímÁr

Strobe DrIVER

Borbála MoHÁcsI

Fruzsina NÉMETH

Eli J. S. WeAVERDYCKE

Aviable online at http://ojs.elte.hu/dissarch

Contact: dissarch@btk.elte.hu

ISSN 2064-4574 (online)

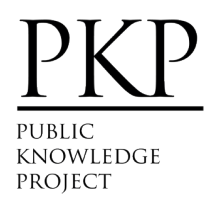

(c ELTE Eötvös Loránd University, Institute of Archaeological Sciences

Layout and cover design: Gábor Váczi

Budapest 2021 


\section{CONTEnTs}

\section{ARTiCles}

Attila PÉNTEK - Norbert FARAgó

Palaeolithic and Mesolithic assemblages from Tunisia

Attila PÉNTEK - Norbert FARAGó

Some remarks on a German chipped stone lithic assemblage of uncertain origin in the collection of the Institue of Archaeological Sciences, Eötvös Loránd University

László Gucsi

Technological observations on a Late Copper Age ceramic assemblage

from Hódmezővásárhely-Kopáncs-Olasz-tanya, Hungary

János Gábor TARBAY

101

A Koszider Period Sword from Tornyospálca-Sírkútgaz (Szabolcs-Szatmár-Bereg County, Hungary)

Ábel GARCZIK

Dolia in the Middle La Tène Period of the Carpathian Basin in the light of new finds from Perkáta-Nyúli-dűlő

Lajos JuHÁsz

An exceptional Sarmatian cast medallion with star and crescent

Gabriella G. DeLBó

New data on the Pannonian glazed casserole handles

Csilla SÁró

The fibula production of Brigetio: Model, semi-finished products, and failed castings

Anita BENES

New data on the capacity of the Roman aqueduct of Brigetio

Melinda SzABó

Status or Role? Differences between the Social Status and Role in Brigetio

Krisztina HoppáL

Roman engraved gems from Southeast Asia 


\section{FiELD REPORTS}

Bence SIMON - Ferenc BARNA

Another barrel-lined well a road section and late Roman graves from Brigetio

Rita RAKONCZAY

Trial excavations in mediaeval churches of Kishartyán, Kisterenye, Mátranovák and Szuha in Nógrád County 2021

\section{Thesis Review Articles}

Tamás KEszi

The change of the pottery style of the Mako and Nagyrév cultures in the Early Bronze Age:

The settlement in Iváncsa-Lapos

Linda Dobosi

Building techniques and building materials in Brigetio:

With the virtual reconstruction of House I/a of the civil town of Brigetio

Csilla SÁRó

Tradition and Romanization by the attire of the Eraviscus tribe 


\title{
New data on the capacity of the Roman aqueduct of Brigetio
}

\author{
Anita Benes \\ Institute of Archaeological Sciences \\ Eötvös Loránd University \\ benesanita@centrum.sk
}

Received 22 December 2021 | Accepted 9 January 2022 | Published 2 March 2022

\begin{abstract}
The aim of the present study is to summarize new results concerning the capacity of the Roman aqueduct of Brigetio (Komárom/Szőny). Hydrological formulae used for calculations on the capacity of aqueducts are described and used to determine the daily discharge of the Roman aqueduct of Brigetio. The results presented are hypothetical, but it is hoped that they reflect the performance of the aqueduct. Calculations on per capita daily water supply and related problems are also addressed.

Keywords: Brigetio (Komárom/Szőny), aqueduct, capacity of aqueducts, per capita water supply
\end{abstract}

\section{Introduction}

The aim of the present study is to summarize new scientific results about the Brigetio (Komárom/ Szőny) aqueduct. Literary sources, maps, scientific references, and the archaeological material regarding the Brigetio aqueduct have already been examined in detail and published in a previous study. ${ }^{1}$ Thus, the present study will treat these sources only to the extent required by the aims of the new examination.

This paper presents the hydrological methods and formulae which enable us to determine the capacity of the aqueducts, and according to them the hypothetical capacity of the Brigetio aqueduct. So far, no section of the Brigetio aqueduct has been observed or excavated by modern archaeological methods. For this reason, the fact that the results presented are hypothetical is emphasized. Besides the capacity of the aqueduct of Brigetio, problems of ancient Roman water usage will be discussed, including the presentation of scientific approaches to the quantity of water supplied to several Roman cities and the difficulties of determining the per capita water supply or usage in ancient Roman times.

\section{Calculation of the capacity of aqueducts}

The capacity of aqueducts that is, the quantity or discharge of water carried by the conduit can be calculated by the following formula: $Q=V A$. In this formula, $Q$ stands for the capacity that can be calculated by multiplying the average velocity of flow ( $V$, measured in $\mathrm{m} / \mathrm{s}$ ) by the cross-sectional area of the wetted perimeter $\left(A\right.$, measured in $\left.m^{2}\right)$. It is noteworthy that we calculate with the cross-sectional area of wetted perimeter, thus with the cross-sectional area where the water in fact 
flows and not the whole cross-sectional area of the conduit. ${ }^{2}$ To calculate the average velocity of flow, we can use either the Chézy formula or the Manning formula. The Chézy formula is expressed as follows: $V=C \sqrt{ } R \times S$. According to this formula, to calculate the velocity of flow we need to know the hydraulic radius of the conduit $(R)$, the slope or the aqueduct gradient $(S)$ and the factor of flow resistance, the so-called Chézy's coefficient $(C)$. The hydraulic radius $(R)$ is defined as the quotient of the cross-sectional area $(A)$ and the wetted perimeter $(P)$ expressed as follows: $A / P$. The slope $(S)$ of the conduit is defined by the head loss $(H)$ per length $(L)$ of the conduit $(H / L)$, which can be expressed in \%o. Regarding the factor of flow, the so-called Chézy's coefficient $(C)$, Antoine Chézy considered it a constant, but the value of the coefficient is defined by the roughness of the surface of the conduit, thus by the degree of friction that the surface of the conduit causes. ${ }^{3}$

For the determination of Chézy's coefficient, several formulae have been created. The GangilletKutter formula was created by two Swiss engineers in 1869. According to this formula, to express Czézy's resistance factor we need to know the slope $(S)$, the hydraulic radius $(R)$ and the coefficient of roughness $(n)$ :

$$
C=\frac{23+\frac{0.00155}{S}+\frac{1}{n}}{1+\left(23+\frac{0.00155}{S}\right) \frac{n}{\sqrt{R}}}
$$

The coefficient of roughness $(n)$ refers to Kutter's $n$ and the formula itself is based on flow-measurement data concerning various types of channels. ${ }^{4}$

In 1897, a new formula was introduced by Emile Bazin to determine Czézy's coefficient (C), which is expressed as follows:

$$
C=\frac{87}{1+m / \sqrt{R}}
$$

In the Bazin formula, $m$ is a coefficient of roughness which is defined in a table (Table 1) and $R$ is the hydraulic radius. According to this formula, the slope $(S)$ does not play a part in determining the factor of flow, i.e., Chézy's coefficient $(C)$. The value of the coefficient of roughness $(m)$ depends on the material and quality of the channel. In order to define the value of $m$, Emile Bazin used data based on small experimental channels. According to later studies, the Gangillet-Kutter formula is more precise than the Bazin formula. ${ }^{5}$

Table 1. Values of Bazin's $m$ for various surface materials and conditions (After CHOw 1959, 95, Tab. 5-1).

\begin{tabular}{|l|l|}
\hline Description of channel & Bazin's $m$ \\
\hline Very smooth cement or planed wood & 0.11 \\
\hline Unplaned wood, concrete or brick & 0.21 \\
\hline Ashlar, rubble masonry or poor brickwork & 0.83 \\
\hline Earth channels in perfect condition & 1.54 \\
\hline Earth channels in ordinary condition & 2.36 \\
\hline Earth channels in rough condition & 3.17 \\
\hline
\end{tabular}

Hodge 1992, 353; CHOw 1959, 93-94.

Hodge 1992, 353-354; CHOW 1959, 93.

CHOw 1959, 94-95.

Chow 1959, 95; Hodge 1992, 354; Gombos 2011, 18.1. 
New data on the capacity of the Roman aqueduct of Brigetio

Table 2. Minimum, normal, and maximum values of Manning's $n$ for lined or constructed channels (After Chow 1959, 111-113, Tabs 5-6).

\begin{tabular}{|c|c|c|c|}
\hline Type of channel and description & Minimum (n) & Normal (n) & $\operatorname{Maximum}(n)$ \\
\hline \multicolumn{4}{|l|}{ I. I. Cement } \\
\hline 1. Neat surface & 0.010 & 0.011 & 0.013 \\
\hline 2. Mortar & 0.011 & 0.013 & 0.015 \\
\hline \multicolumn{4}{|l|}{ II. Concrete } \\
\hline 1. trowel finish & 0.011 & 0.013 & 0.015 \\
\hline 2. float finish & 0.013 & 0.015 & 0.016 \\
\hline 3. finished with gravel on bottom & 0.015 & 0.017 & 0.020 \\
\hline 4. unfinished & 0.014 & 0.017 & 0.020 \\
\hline 5. gunite, good section & 0.016 & 0.019 & 0.023 \\
\hline 6. gunite, wavy section & 0.018 & 0.022 & 0.025 \\
\hline 7. on good excavated rock & 0.017 & 0.020 & - \\
\hline 8. on irregular excavated rock & 0.022 & 0.027 & - \\
\hline \multicolumn{4}{|c|}{ III. Concrete bottom float finish with sides of: } \\
\hline 1. dressed stone in mortar & 0.015 & 0.017 & 0.020 \\
\hline 2. random stone in mortar & 0.017 & 0.020 & 0.024 \\
\hline 3. cement rubble masonry, plastered & 0.016 & 0.020 & 0.024 \\
\hline 4. cement rubble masonry & 0.020 & 0.025 & 0.030 \\
\hline 5. dry rubble or riprap & 0.020 & 0.030 & 0.035 \\
\hline \multicolumn{4}{|l|}{ IV. Gravel bottom with sides of: } \\
\hline 1. formed concrete & 0.017 & 0.020 & 0.025 \\
\hline 2. random stone mortar & 0.020 & 0.023 & 0.026 \\
\hline 3. dry rubble or riprap & 0.023 & 0.033 & 0.036 \\
\hline \multicolumn{4}{|l|}{ V. Brick } \\
\hline 1. glazed & 0.011 & 0.013 & 0.015 \\
\hline 2. in cement mortar & 0.012 & 0.015 & 0.018 \\
\hline \multicolumn{4}{|l|}{ VI. Masonry } \\
\hline 1. cemented rubble & 0.017 & 0.025 & 0.030 \\
\hline 2. dry rubble & 0.023 & 0.032 & 0.035 \\
\hline \multicolumn{4}{|l|}{ VII. Dressed ashlar, stone paving } \\
\hline & 0.013 & 0.015 & 0.017 \\
\hline \multicolumn{4}{|l|}{ VIII. Vegetal lining } \\
\hline & 0.030 & - & 0.500 \\
\hline
\end{tabular}


In 1889, Robert Manning created a new formula to determine the factor of flow $(C)$, which is expressed as $C=K R^{1 / 6}$. In this formula, $K$ refers to a coefficient that determines the roughness of a certain channel. In order to determine the K coefficient, we need the reciprocal value of Manning's $n$ coefficient of roughness, which is expressed as $K=1 / n$. The value of $n$ is determined by the quality of the surface (Table 2): as the surface gets rougher the value of $n$ increases and the value of $K$ decreases. ${ }^{6}$

In the case of Roman aqueducts, which were lined with smooth plastered concrete (terrazzo), the factor of flow, i.e., the $C$ coefficient is always between the values of 60 and 80 . The smoother and newer the work, the higher the value of the $C$ coefficient. ${ }^{7}$ Based on the formulae described above, we can calculate the capacity of Roman aqueducts if we know the slope of the aqueduct, the size of the channel, the height of the water carried in the channel, and the factor of flow, i.e., the $C$ coefficient.

\section{The capacity of the Roman aqueduct of Brigetio}

Due to the fact that, unfortunately, no section of the aqueduct channel has been studied by modern archaeological methods, for the Roman aqueduct of Brigetio, only a hypothesis can be built on its capacity. Regarding the route and the length of the aqueduct and the size of the channel, we have to rely on maps and literary sources that mention the aqueduct. Thanks to the literary sources, we can formulate an idea of its structure, construction, and size. ${ }^{8}$

Tab. 3. Length and discharge of Roman aqueducts (after Hodge 1992, 347-348).

\begin{tabular}{|l|l|l|}
\hline Aqueduct & Lenght of channel $(\mathrm{km})$ & Discharge $(\mathrm{m} 3 / 24 \mathrm{hrs})$ \\
\hline Aqua Appia (Rome) & 16 & 73,000 \\
\hline Aqua Anio Vetus (Rome) & 64 & 175,920 \\
\hline Aqua Marcia (Rome) & 91 & 187,600 \\
\hline Aqua Tepula (Rome) & 18 & 17,800 \\
\hline Aqua Iulia (Rome) & 23 & 48,240 \\
\hline Aqua Virgo (Rome) & 21 & 100,160 \\
\hline Aqua Alsietina (Rome) & 33 & 15,680 \\
\hline Aqua Claudia (Rome) & 69 & 184,220 \\
\hline Aqua Anio Novus (Rome) & 87 & 189,520 \\
\hline Aqua Traiana (Rome) & 58 & 113,920 \\
\hline Aqua Alexandrina (Rome) & 22 & 21,160 \\
\hline Metz & 22 & 22,000 \\
\hline Nimes & 50 & 20,000 \\
\hline Sens & 17 & 40,760 \\
\hline Cologne & 94.5 & 21,600 \\
\hline Trier & 13 & 25,450 \\
\hline Carthage & 84 & 17,280 \\
\hline Cherchel & 45 & 40,000 \\
\hline Bologna & 20 & 35,000 \\
\hline
\end{tabular}

8 See BENEs 2018 for maps and literary sources concerning the Roman aqueduct of Brigetio. 
Based on literary sources, maps, and studies concerning the structure and construction of the aqueduct, we conclude that it consisted partly of a vaulted channel running near the surface, partly in a ramp, therefore it was a surface channel, ${ }^{9}$ and partly the aqueduct channel was built on arcades above the level of the surface. The construction consisted of bricks, stone, and tuff stuffed with lime. ${ }^{10}$ The size of the vaulted surface channel running in a ramp at least at the intact section near Bélapuszta observed by Rudolf Gyulai was one meter high, and $0.8 \mathrm{~m}$ wide. The length of the aqueduct according to the available literary sources was between 15.2 and $15.75 \mathrm{~km}$. To determine the slope of the aqueduct, we need the levels of the starting point and the endpoint. As the endpoint of the aqueduct, we can assign the foreground of the south gate of the legionary camp, ${ }^{11}$ which is located $107 \mathrm{~m}$ above sea level. It is more difficult to define the starting point of the aqueduct, in other words, to determine the location of the spring that supplied it.

According to literary sources, maps, and studies, the following locations are the possible options: the spring of Kökút Köz, ${ }^{12}$ the spring of the Eszterházy Hospital, ${ }^{13}$ the springs in the area of the Old Lake, ${ }^{14}$ and the Fényes Springs. ${ }^{15}$ I used the daily discharge values estimated by Henrik Horusitzky in $1919 .{ }^{16}$

According to the discharge values described above, the Romans must have used the abundant sources of either the Fényes Springs or the Great Spring under the Castle to supply the Brigetio aqueduct. The Great Spring under the Castle is located $118 \mathrm{~m}$ above sea level. The Fényes Springs are located 118-119 $\mathrm{m}$ above sea level. If we assign the foreground of the south gate of the legionary camp as the endpoint of the aqueduct, which is located $107 \mathrm{~m}$ above sea level, and we count with a $15.75 \mathrm{~km}$ long route, ${ }^{17}$ the difference between the level of the starting point and that of the endpoint of the aqueduct is $11 \mathrm{~m}$ in the case of the Great Spring under the Castle. This means the slope of the aqueduct would be $0.69 \%$. In the case of the Fényes Springs, the difference between the levels

9 Following the terminology of HodGE 1992, 93: surface channel - 'a conduit that closely followed the surface of the land, instead of being raised on arches or sunk deep beneath it in a tunnel'.

10 Marsigli 1726, 3; BÉL 1989, 80, 93, 96; National Archives of Hungary Fasc. 39, Nr. 63; Gyulai 1885; Gyulai 1886.

11 I assigned the foreground of the south gate of the legionary camp as the endpoint of the aqueduct based on the maps of Sámuel Mikoviny (National Archives of Hungary S. 11 No. 290), Rudolf Gyulai (GyULAI 1886, 333.), and Milos Berkovics-Borota (Berkovics-Borota 1886, 393).

12 Based on Sámuel Mikoviny’s map, Bence Simon and László Rupnik suppose that the spring of Kőkút Köz supplied the aqueduct. The estimated daily discharge of the spring of Kőkút Köz in 1919 was 32.4 1/min, which means the daily discharge of the spring was $46.656 \mathrm{~m}^{3}$. If we suppose the aqueduct collected the water of the springs of Komárom Street, the daily discharge increases by 1,800 l/min, which equals 2,592 $\mathrm{m}^{3}$ /day. Overall, the total daily discharge of the springs of Komárom Street and Kőkút Köz is $2,638.656 \mathrm{~m}^{3}$.

13 Gyulai 1885. In the case of the spring of the Eszterházy Hospital (recently called the springs of the Castle Garden), which is located $135.3 \mathrm{~m}$ above sea level, the daily discharge was $60 \mathrm{l} / \mathrm{min}$, which amounts to $86.4 \mathrm{~m}^{3}$ /day according to the estimations made in 1919 .

14 Gyulai 1886; Berkovics-Borota 1886, 393. Regarding the area of the Old Lake, the Great Spring under the Castle located at $118 \mathrm{~m}$ above sea level had considerable discharge. According to the data given by Henrik Horusitzky, its discharge was 10,998 1/min, thus we can count with a daily discharge of $15,837.12 \mathrm{~m}^{3}$.

15 Paulovics 1941, 145-151; Of the above options, the Fényes Springs had the highest discharge. The springs are located 118-119 $\mathrm{m}$ above sea level and their discharge was $81,000 \mathrm{l} / \mathrm{min}$, which means a daily discharge of 116,640 $\mathrm{m}^{3}$ according to the estimated data from 1919.

16 Horusitzky 1923. For a detailed description of the springs of Tata and the possible sources of the aqueduct of Brigetio, see: BenEs 2018, 425-428, Tab. 1, Fig. 7.

17 I count with a $15.75 \mathrm{~km}$ long aqueduct route, according to data given by Milos Berkovics-Borota (BERKOVICS-BOROTA 1886, 393.). 
is $11-12 \mathrm{~m}$, thus the slope of the aqueduct would be $0.69 \%$ to $0.76 \%$. These values differ from the values suggested by Vitruvius (5\%) (Vitruvius: De Arch. 8. 6. 1.) and Plinius $(0,2 \%)$ (Plinius: Nat. Hist. 31. 57). However, aqueducts with similar slopes are common in the Roman Empire. ${ }^{18}$

To determine the capacity of the aqueduct $(Q)$, as described above, we need to know the average velocity of the flow $(V)$ of the water in the channel and the cross-sectional area of the wetted perimeter $(A)$, as the capacity is calculated by multiplying these values: $Q=V A$. For the calculation of the size of the cross-sectional area of the wetted perimeter, we need to know the height of the water in the aqueduct channel and the width of the channel. Based on the description of Rudolf Gyulai, the vaulted channel of the Brigetio aqueduct was one meter high and $0.8 \mathrm{~m}$ wide. ${ }^{19}$ Considering the ancient Roman practice, we can assume that the aqueduct channel was only half to two thirds full of water. ${ }^{20}$ In the case of a channel half full, we can calculate the cross-sectional area of the wetted perimeter as follows: $A=0.8 \mathrm{~m} \times 0.5 \mathrm{~m}$, which equals $0.4 \mathrm{~m}^{2}$. To calculate the average flow of water in the channel, we can use the Chézy formula: $V=C \sqrt{ } R \times S$. The size of the hydraulic radius ${ }^{\circledR}$ equals the quotient of the cross-sectional area of the wetted perimeter $(A)$ and the wetted perimeter $(P): R=A / P$. Thus, in the case of the Brigetio aqueduct, we can calculate with $0.4 \mathrm{~m}^{2} / 1.8 \mathrm{~m}$, which equals $0.222 \mathrm{~m}$.

The slope $(S)$ of the aqueduct is defined by the head loss $(H)$ per length $(L)$ of the channel $(H / L)$, which can be expressed in \%. As noted above, based on the discharge of springs in Tata, the Great Spring under the Castle (118 $\mathrm{m}$ above sea level) and the Fényes Springs (118-119 m above sea level) must have been able to supply the aqueduct. As the endpoint of the aqueduct probably we can assign the foreground of the south gate of the legionary camp (107 $\mathrm{m}$ above sea level). Calculating with these options, the difference between the levels of the starting point and the endpoint, i.e., the head loss of the aqueduct is $11 \mathrm{~m}$ in the case of the Great Spring under the Castle, and 11-12 $\mathrm{m}$ in the case of the Fényes Springs. Regarding the length of the route of the aqueduct, I have opted for using the length given by Milos Berkovics-Borota, ${ }^{21}$ as he also located the source of the aqueduct in the vicinity of the Castle. Therefore, the slope of the aqueduct in the case of the Great Spring under the Castle is $11 \mathrm{~m} / 15.750 \mathrm{~m}=0.00069841$, which means $0.69 \%$. For the Fényes Springs, this value is $11 \mathrm{~m} / 15.750 \mathrm{~m}=0.00069841$ or $12 \mathrm{~m} / 15.750 \mathrm{~m}=0.00076190$, which means $0.69 \%$ or $0.76 \%$. As both options are possible, I have calculated the capacity of the aqueduct for both.

Besides the values listed above, we need the factor of flow, the so-called Chézy's coefficient (C) in the calculation of the capacity of the aqueduct. In the case of ancient Roman aqueducts which were lined with smooth plastered concrete (terrazzo), the $C$ coefficient is always between the values of 60 and 80. The smoother and newer the construction, the higher the value of the $C$ coefficient. ${ }^{22}$ Considering the fact that no section of the aqueduct has been studied by modern archaeological methods, I decided to calculate with both the lowest and the highest value of the $C$ coefficient.

Using the Chézy formula, the average velocity of the water flow in the channel is $0.75 \mathrm{~m} / \mathrm{s}$ if the slope is $0.69 \%$, and the $C$ coefficient is 60 ; thus in an older or less elaborated, rougher channel. If the slope is the same, but the $C$ coefficient is 80 , therefore in the case of a smoother and newer channel, the average velocity is $1 \mathrm{~m} / \mathrm{s}$. If the slope is $0.76 \%$ ond the $C$ coefficient is 60 , the average velocity of the water flow in the channel is $0.78 \mathrm{~m} / \mathrm{s}$, if the $C$ coefficient is 80 ; thus, for a smoother channel, this value is $1.04 \mathrm{~m} / \mathrm{s}$. 
According to the calculations above, we may suppose that the average velocity of the water flow in the channel was between $0.75 \mathrm{~m} / \mathrm{s}$ and $1.04 \mathrm{~m} / \mathrm{s}$. Calculations for capacity have been made with both values of the average velocity of the water flow in the channel. In order to calculate the capacity of the aqueduct, as noted above, the average value of the velocity of the water flow in the channel has to be multiplied by the size of the cross-sectional area of the wetted perimeter. In the case of the Brigetio aqueduct, calculating with an $0.40 \mathrm{~m}^{2}$ cross-sectional area of the wetted perimeter and the lower value of the velocity of water flow in the channel, thus with $0.75 \mathrm{~m} / \mathrm{s}$, the capacity is: $0.40 \times 0.75=0.3 \mathrm{~m}^{3} / \mathrm{s}$. This means $18 \mathrm{~m}^{3} / \mathrm{min}, 1,080 \mathrm{~m}^{3} / \mathrm{h}$, and $25,920 \mathrm{~m}^{3} /$ day. Calculating with the higher value of average velocity of water flow in the channel, thus with $1.04 \mathrm{~m} / \mathrm{s}$, the capacity of the aqueduct is $0.40 \times 1.04=0.416 \mathrm{~m}^{3} / \mathrm{s}$, which means $24.96 \mathrm{~m}^{3} / \mathrm{min}, 1,497.6 \mathrm{~m}^{3} / \mathrm{h}$, and $35,942.4 \mathrm{~m}^{3} /$ day. Rounding these values of capacity, we may suppose the daily discharge of the Roman aqueduct of Brigetio was between $26,000 \mathrm{~m}^{3}$ and $36,000 \mathrm{~m}^{3}$. It is important to note that the results are hypothetical because of several reasons: the size of the aqueduct channel might have been different in certain sections,$^{23}$ the slope of the aqueduct might differ in sections of the channel, and the height of the water in the channel could also vary. All these factors had an impact on the capacity of the aqueduct, and the results are based on the limited data available, thus are to be handled with caution. However, these hypothetical results represent the efficiency of the Roman aqueduct of Brigetio. Even calculating with the lowest values, we have a daily discharge of $26,000 \mathrm{~m}^{3}$, which might seem very high, but for Roman aqueducts this capacity is average (Table 3).

The best-known Roman aqueduct in Pannonia from an archaeological point of view is that of Savaria (Szombathely). Thanks to modern archaeological excavations on different sections of the aqueduct channel, we are able to study its hydrology. Regarding the capacity of the Roman aqueduct of Savaria, Krisztián Anderkó has recently published his results. On the basis of two Austrian sections of the aqueduct channel with average permeability, he has calculated the capacity of the aqueduct in the case of maximal utilization of the channel and has obtained the results of $76,000 \mathrm{~m}^{3} /$ day and $163,200 \mathrm{~m}^{3} /$ day. Due to the slope between the starting point and the endpoint, which is $9.1 \%$, the capacity of the aqueduct is very high. Based on the wear and scaling process observed on a section of the channel in Bucsu, he assumes that only 50 to $60 \%$ of the channel was in fact filled with water. ${ }^{24}$ This means we should count with half of the above discharge values to estimate the actual daily discharge of the aqueduct, which in this case is between $38,000 \mathrm{~m}^{3} /$ day and $81,600 \mathrm{~m}^{3} /$ day. These values are significantly higher than the hypothetical results regarding the capacity of the Brigetio aqueduct.

The hypothetical results regarding the capacity of the Brigetio aqueduct confirm the former assumption that the source of the aqueduct might have been either the Great Spring under the Castle or the Fényes Springs. According to the hypothetical capacity calculated, the aqueduct could easily transport the $15,837.12 \mathrm{~m}^{3}$ daily discharge of the Great Spring under the Castle. Regarding the enormous discharge of the Fényes Springs, the aqueduct would have been unable to transport the entire $116,640 \mathrm{~m}^{3}$ daily discharge of all the springs, but if the source of the aqueduct was located here, we can consider that it was not necessary to use all the springs to supply the aqueduct. 


\section{Ancient Roman per capita water supply}

The problem of ancient Roman per capita water usage and per capita water supply is an unresolved historical problem. Neither the literary sources nor the archaeological evidence provide enough and appropriate data regarding the determination of per capita water usage or per capita water supply in Roman times. Although it is possible to calculate the capacity of certain aqueducts, in most cases the extent of utilization of the channel remains unknown. Another problem is that we are unable to capture temporal changes in the utilization of the aqueducts. ${ }^{25}$ However, it can be established that the size of an aqueduct channel was determined not only by the amount of water it had to carry, but ample space had to be provided for maintenance and cleaning work as well. ${ }^{26}$ It also has to be noted that aqueduct channels were never running full: they were normally filled half to two thirds. ${ }^{27}$

Another uncertainty is the population of ancient Roman settlements. We do not have reliable data even for the population of Imperial Rome in any period. The generally accepted assumption regarding Rome's Frontinus era population is approximately one million. ${ }^{28}$ The estimated values regarding the total daily discharge of Rome's aqueducts are also different, therefore the estimated per capita daily supply also varies on a wide range. According to Pietrantonio Pace, the total daily discharge of Rome's aqueducts was $1,010,000 \mathrm{~m}^{3},{ }^{29}$ while the estimate of Trevor A. Hodge on the total daily discharge gives a value between 700,000 and a million cubic meters. ${ }^{30}$ Henning Fahlbusch assumes it was between 520,000 and 635,000 $\mathrm{m}^{3,},{ }^{31}$ while according to Deane Blackman, the total daily discharge was approximately 560,000 to $620,000 \mathrm{~m}^{3} \cdot{ }^{32}$ Another problem is the daily per capita water supply, as it is usually calculated simply by the division of the above listed estimated total discharge values by the estimated population numbers. However, the resulting figure might be misleading because this method does not yield actual and useful results. One reason is that the water distribution between inhabitants was unequal. For example, the higher classes of society had their private water supply. In addition, a significant proportion of the water supplied was used by baths, latrines, and fountains.

These issues are highlighted in a study by Christer Bruun regarding the daily per capita water supply in Imperial Rome. According to Bruun, the total daily discharge of Rome's aqueducts was approximately $600,000 \mathrm{~m}^{3}$. Calculating with a population of one million, the per capita daily water supply was $0.6 \mathrm{~m}^{3}$. This figure might be misleading because water was not distributed equally between the public and the private spheres. According to Frontinus, the aqueducts of Rome served 591 major delivery points, so-called laci. ${ }^{33}$ Bruun estimated each lacus could supply $60 \mathrm{~m}^{3}$ of water on a daily basis, and each lacus served 900 inhabitants, thus the daily per capita water supply was $0.067 \mathrm{~m}^{3}$. This amount might seem low but it reflects only the laci. In addition, Rome's inhabitants could also use the water supplied by public fountains, baths and latrines, as well as the water of the Tiberis and rainwater collected in cisterns. ${ }^{34}$ Roger D. Hansen has found the daily $0.067 \mathrm{~m}^{3}$ amount

ANGELAKIS et al. 2012, 32; HANSEN 2019, 6.

HANSEN 2019, 6.

HodGe 1992, 94-95.

Angelakis et al. 2012, 32; BruUn 1991, 101; HANSEN 2019, 6.

PACE 1986, 151.

Hodge 1984, 207.

FAHLBUSCH 1982, 137, 144.

BLACKMAN 1978, 71.

Frontinus: De Aq. II. 78.3.

BRUUN 1991, 97-104. 
per capita supplied by the laci satisfactory. Moreover, in comparison, he notes that the average daily water consumption per capita in the U.S.A. in the $1990 \mathrm{~s}$ was $0.25 \mathrm{~m}^{3}$. He also mentions that Roman water supply was fundamentally different compared to modern water supply. Modern water supply is of the 'on-demand' type, while the ancient Roman water supply was constant, because the water was running all the time in conduits, channels, latrines, and fountains. Therefore, it might lead to false conclusions if we compared the per capita water use of Rome with contemporary figures. ${ }^{35}$ According to Bruun, for the Romans the constant day and night flow of water was a symbol of wealth. On the other hand, they highly valued water. Although Frontinus does not refer to saving water, archaeological excavations have unearthed taps ${ }^{36}$ used in the water distribution system that provide evidence for the 'on-demand' type of water usage. Furthermore, the different types and sizes of cisterns also refer to saving water. ${ }^{37}$

To sum up, concerning the discharge of Roman aqueducts and the per capita daily water supply, unfortunately, we do not have enough scholarly and archaeological evidence. Nevertheless, based on available estimations, Imperial Rome was able to adequately supply approximately one million people, which must have been a great achievement.

Hans Eschebach estimates the water usage and supply of the city of Pompeii. Based on the fact that a total of 40 public fountains have been discovered in the excavated area, i.e., in about two-thirds of the entire city, he puts the total number of public fountains at 50. With an estimated population of 8,000 , this means each public fountain served 160 inhabitants. The fountains were located approximately 100 meters apart, thus there was one available for every single inhabitant within 50 meters. The estimated daily discharge of the aqueduct is $6,480 \mathrm{~m}^{3}$. Calculating with $0.5 \mathrm{~m}^{3}$ daily per capita water usage, a total of $4,000 \mathrm{~m}^{3}$ of water was used by the inhabitants, and 2,480 $\mathrm{m}^{3}$ was left for other public and industrial use. ${ }^{38}$ Regarding the estimated figures of the daily per capita consumption, Hodge notes calculating with a consumption of a daily $0.5 \mathrm{~m}^{3}$ per capita is excessively generous, especially compared to a person's minimal daily need of about $0.01 \mathrm{~m}^{3}$. The estimations of Eschebach do not take account of inhabitants who had their own private water supply and probably did not use the public fountains. Besides, there were further supplies of water thanks to the wells and cisterns available. Overall, the aqueduct seems to have carried sufficient amounts of water to supply the estimated 8,000 inhabitants of Pompeii. ${ }^{39}$

For the population of Brigetio, unfortunately, we do not have any estimates. Taking into account the city's importance, we can calculate with approximately 20,000 to 25,000 inhabitants concerning the whole population of the legionary camp, the canabae and the municipium, as only the legionary camp was made up of at least 10,000 persons. ${ }^{40}$ According to the above calculations on the hypothetical capacity of the Brigetio aqueduct, it seems that it managed to supply the entire city with fresh water. It appears that the earlier defined hypothetical 26,000 to $36,000 \mathrm{~m}^{3}$ daily discharge was needed for the city. The recently discovered Roman bath on the territory of the canabae, which has so far been excavated in an area of some $900 \mathrm{~m}^{2}$, but whose full size is unknown, ${ }^{41}$ also needed

35 HANSEN 2019, 6.

36 Taps were not uncommon in the Roman water network system. They served two functions: they were either moulded over a sink or bath, or they were inserted where pipes branched off to shut off the supply when needed. For further details, see: HodGE 1992, 322-326.

37 BRUUN 1991, 112-114.

38 EsCHEBACH 1983, 100-101.

39 Hodge 1992, 304-306.

40 According to the verbal communication of my director of studies, Prof. László Borhy. Hereby, I would like to express my gratitude for his advice and support in my research.

41 BARtus et al. 2016a, 65-67; BARTus et al. 2016b, 338-339. 
significant amounts of water. As described above, to calculate the daily per capita water supply, we can devise the daily discharge of the aqueduct, but we have to remember that, because of the reasons given above, the value is only a hypothetical 'guiding' figure, not reflecting the actual situation. However, based on the available data, this is the only way to calculate the daily per capita water supply. For Brigetio, I have calculated the daily per capita consumption using both the minimal and the maximal results on the daily discharge of the aqueduct, and have also made calculations with both the minimal and the maximal estimated numbers of inhabitants. Calculating with the minimal values in both cases, that is with $26,00 \mathrm{~m}^{3}$ and 20,000 inhabitants, the daily per capita water consumption or supply is $1.3 \mathrm{~m}^{3}$. Calculating with the minimal daily discharge of the aqueduct and the maximal number of inhabitants, that is with $26,000 \mathrm{~m}^{3}$ and 25,000 inhabitants, the daily per capita water supply is $1.04 \mathrm{~m}^{3}$. If counting with the maximal daily discharge of the aqueduct and the minimal number of inhabitants, that is with $36,000 \mathrm{~m}^{3}$ and 20,000 inhabitants, the daily per capita water supply is $1.8 \mathrm{~m}^{3}$. Calculating with both the maximal discharge and the maximal number of inhabitants, that is with $36,000 \mathrm{~m}^{3}$ and 25,000 inhabitants, the result on the daily per capita water supply is $1.44 \mathrm{~m}^{3}$.

To sum up, according to the calculations based on hypothetical and estimated data of the capacity of the aqueduct and the number of inhabitants, the daily per capita water supply was between 1.04 and $1.8 \mathrm{~m}^{3}$. This might seem very high but it has to be remembered that this is a 'guiding' figure, and due to the lack of information, more accurate estimation seems impossible.

In conclusion, concerning Roman water usage and supply, there are several unknown factors. Although the capacity of the aqueducts can be estimated, the estimation of the daily per capita water supply is more difficult because the water was not distributed equally among the inhabitants. Furthermore, we know that cisterns, wells, rivers, and lakes also provided water, but unfortunately, we have no methods to measure the amounts they provided.

\section{Summary}

The aim of the present study is to introduce new data on the Roman aqueduct of Brigetio and on the daily per capita water supply in the city. Based on the available information, calculations have been made to gauge the capacity of the aqueduct. Unfortunately, no section of the aqueduct has been studied by modern archaeological methods, therefore the results presented in the study are hypothetical and based on indirect sources. Consequently, results should be interpreted with caution. The size of the channel, the slope of certain sections, and also the height of the water in the channel could vary, which had an effect on the capacity of the aqueduct. In addition, the results are based on the limited data available.

It is calculated that the estimated daily discharge of the aqueduct was between $26,000 \mathrm{~m}^{3}$ and $36,000 \mathrm{~m}^{3}$. Based on this figure and a population of 20,000 to 25,000, in Brigetio the estimated daily per capita water supply was between 1.04 and $1.8 \mathrm{~m}^{3}$.

\section{Sources}

Frontinus: De aquaeductibus Urbis Romae.

PuINIUs: Naturalis Historia.

VITRUVIUS: De architectura libri decem. 


\section{Bibliography}

Anderkó, K. 2006: Savaria vízvezetéke (The Savarian aquaeductus). Savaria - A Vas Megyei Múzeumok Értesitóje 30, 9-46.

Angelakis, A. N. - Mays, L. W. - Koutsoyiannis, D. - Mamassis, N. 2012: Evolution of Water Supply Through the Millennia. London.

Bartus, D. - Borhy, L. - CzAjlik, Z. 2016a: Recent research in the canabae and legionary fortress of Brigetio (2014-2015). In: BeszéDes, J. (ed.): Legionary fortress and canabae legionis in Pannonia. International Archaeological Conference. 16-17. November, 2015. Aquincum Nostrum II:7. Budapest, 63-72.

BArtus, D. - Borhy, L. - Sey, N. - SzÁmadó, E. 2016b: Short report on the excavations in Brigetio in 2016. Dissertationes Archaeologicae 3/4, 337-350. DOI: 10.17204/dissarch.2016.337

BÉL, M. 1989: Komárom vármegye. Az újkori Magyarország földrajzi-történelmi ismertetése. Csallóközi Kiskönyvtár. Pozsony.

Benes, A. 2018: The Roman aqueduct of Brigetio. Dissertationes Archaeologicae 3/6, 419-440. DoI: 10.17204/ dissarch.2018.419

Berkovics-Borota, M. 1886: Ásatásom az ó-szőnyi római táborban. Archaeológiai Értesítő 6, 392-397.

Blackman, D. R. 1978: The Volume of Water Delivered by the Four Great Aqueducts of Rome. Papers of the British School at Rome 46, 52-72. DOI: 10.1017/S0068246200011417

Bruun, C. 1991: The Water Supply of Ancient Rome. A Study of Roman Imperial Administration. Commentationes Humanarum Litterarum 93. Helsinki. DoI: 10.1017/S0009840X00284345

CHow, V. T. 1959: Open-channel Hydraulics. Tokyo.

Eschebach, H. 1983: Gebrauchswasserversorgung Pompejis. In: Boucher, J.-P. (ed.): fournées d'Études sur les Aqueducs romains. Paris, 81-132.

FAHLBusch, H. 1982: Vergleich antiker griechischer und römischer Wasserversorgungsanlagen. Mitteilungen Leichtweiss-Institut für Wasserbau der Technischen Universität Braunschweig 73. Braunschweig.

Gomвоs, B. 2011: Hidraulika-hidrológia. https://www.tankonyvtar.hu/hu/tartalom/tamop412A/20100019_hidrologia-hidraulika/ch18.html (last access: 20. 11. 2021).

GyulaI, R. 1885: A Bregetiumi vízvezetékről. Archaeologiai Értesítő 5, 332-335.

Gyulai, R. 1886: Második levele a bregetiumi vízvezetékről. Archaeologiai Értesítő 6, 348-350.

HANSEN, R. D. 2019: Water and Wastewater Systems in Imperial Rome. http://www.waterhistory.org/histories/ rome/rome.pdf (last access: 27. 05. 2019).

Hodge, T. A. 1984: How did Frontinus measure the Quinaria? American fournal of Archaeology 88, $205-216$. DOI: $10.2307 / 504996$

Hodge, T. A. 1992: Roman Aqueducts \& Water Supply. London.

HoRusitzky, H. 1923: Tata és Tóváros környékének hidrogeológiája és közgazdasági jövője. A Magyar Királyi Földtani Intézet Évkönyve 25:3. Budapest.

Marsigli, L. F. 1726: Danubius Pannonico-Mysicus I. Amsterdam.

PACE, P. 1986: Tecniche di conduzione e distribuzione dell'acqua in epoca romana. In: Il trionfo dell'acqua. Acque e acquedotti a Roma. Mostra Museo della Civiltà Romana. Roma, 138-151.

PAulovics, S. 1941: Funde und Forschungen in Brigetio (Szőny). Laurae Aquincenses memoria Valentini Kuzsinszky dicatae, I-II. Dissertationes Pannonicae II/10-11, 118-164.

(C) 2022 The Author(s).

(c) (1) 5 This is an open-access article distributed under the terms of the Creative Commons Attribution-Non Commercial 4.0 International Licence (CC BY-NC 4.0). 
